\title{
US Congress gives go-ahead to Third World institute
}

LEGISLATION establishing a new Institute for Scientific and Technological cooperation (ISTC) was approved in both houses of the US Congress last week, following the Senate's agreement to drop its previous opposition to the scheme. Although the budget of the ISTC still has to be agreed, the decision means that the US will be able to present the institute as a definite initiative to the United Nations Conference on Science and Technology for Development in Vienna.

Plans for the institute, first announced by President Carter last year and included in his budget request for 1980 presented to Congress in January, had been "derailed" by the Senate in June. The action took the form of an amendment to the Development Aid Authorisation Bill originally offered by Senator Deconcini, who objected to what he claimed was a "new federal bureaucracy" which would duplicate work already being done elsewhere. Meanwhile, the House of Representatives had approved the ISTC proposal, but recommended against the Administration's wishes, that the Peace Corps be made an autonomous agency within the newly-established international development cooperation agency.

The Administration, with a big political stake in the ISTC proposal, was able to watch the two decisions played off against each other during a series of conference meetings between delegates representing the two houses - the formal procedure by

\section{Pakistan considers uranium enrichment}

Pakistan has an ambitious nuclear power programme and, consequently, it is concerned that unless it acquires the capacity to enrich uranium locally, its energy supply will be highly vulnerable.

Two years ago, Canada backed out of the contract it had with Pakistan to provide fuel for KANUPP (the Karachi Nuclear Power Plant which it had already installed) over the issue of whether or not Pakistan was to acquire a reprocessing plant from France. "What do you expect us to do after the experience at KANUPP", said one Pakistani scientist. "If we had not developed the capability of fuelling KANUPP on our own, the $137 \mathrm{MW}$ power plant would have been written-off'".

Similarly, a $600 \mathrm{MW}$ reactor being built at Chashma in north Pakistan, received a setback when France backed out of a deal to deliver a reprocessing plant to Pakistan after pressure from the US. Nevertheless, Pakistan's nuclear think-tank forsees many nuclear reactors of either the US light water type or the advanced gas-cooled type being built in the $1980 \mathrm{~s}$. Such reactors run on enriched uranium ( $3 \%$ or a little less). which differences are ironed out before legislation can be agreed. After three separate meetings, it was agreed to accept the House position approving the ISTC and the Senate position on the peace corps, thus satisfying the Administration on both counts.

The conference report, which was subsequently accepted by the full House and Senate, also stated that the amount of new money it was prepared to authorise for the ISTC should be cut from the $\$ 25$ million in the President's request to $\$ 23.75$ million. Initially the bulk of the institute's research funds will come from the transfer of research projects already underway within the Agency for International Development (AID). The precise budget will not be settled until both houses agree to foreign aid appropriations next month. The conference also agreed to accept the modifications which the House had previously made to the Administration's proposal for the ISTC. In particular, it has strengthened the role of the governing council so that it will have the right to review (although not, as some would have liked, to veto) all projects costing more than $\$ 200,000$ or lasting more than two years. The new institute will have two main functions: to support research into topics of direct relevance to the developing countries and to help stimulate the development of research facilities within the developing countries.

David Dickson

KANUPP, the only nuclear power reactor in the country at present, runs on natural uranium.

With the development of the centrifuge technique, uranium enrichment is no longer beyond the reach of the developing countries. Previously uranium enrichment had relied solely on gaseous diffusion. The situation, however, is now changing. In 1977, even the President of the US approved the gas-centrifuge technique and opposed the construction of a large and costly diffusion enrichment plant.

The centrifuge technique appears to have advantages over diffusion methods where the output of enriched uranium needed is small. A centrifuge complex can be built in stages and a start can be made with only a few hundred centrifuges.

Apart from the advantage that the centrifuge technique presents, Pakistan also possesses two other assets over other developing nations. It has about 500 nuclear scientists/engineers, and sizeable uranium deposits in the Dera Ghazi Khan district.

Azim Kidwai

\section{HSE to review safety at Windscale}

FOLLOWING the latest incident of a fire at Windscale where five workers suffered low level $\mathrm{Cs}^{137}$ contamination, the UK Health and Safety Executive has announced that it will conduct a review of the plant's safety arrangements. A review team consisting of Mr Fen Charlesworth, Senior Deputy Chief Inspector of the Nuclear Installations Inspectorate, $\mathrm{Mr}$ Bill Kenney of the Department of the Environment, Mr Stan Gronow from the HSE and a fourth independent specialist to be announced, will investigate safety management, safety surveillance and safety assessment procedures at the reprocessing plant.

The committee has taken the unusual step of announcing ahead of time that it will publish its findings. An HSE official told Nature that the large number of incidents at the plant and public concern about the plant's safety have made the HSE want to "let the public see what we are doing about Windscale". According to HSE records the Windscale plant has had 75 incidents since December 1976. Of these, three incidents in addition to the fire are considered major: a still unlocated leak in the B38 silo, a potentially explosive hydrogen build up in the same storage building, and a sump leaking 20,000 curies into the soil earlier this year.

The team will call independent consultants, chosen for specific expertise. They are not expected to include wellknown critics of Windscale safety procedures such as Dr Michael Flood and Walt Patterson of Friends of the Earth.

The general investigation has preempted a review of the cause of the latest fire leaving numerous questions unanswered. The fire occurred when a fuel disassembly apparatus jammed in a decanning cave. The fire had to be put out manually and radiation escaped contaminating the five workers and causing fallout outside the building. The exact sequence of events is unknown and the questions raised by the incident are central to Windscale safety precautions. These include; how the fire began, why the installed sprinker system failed to put it out, why the fire burned for as long as $\mathbf{4 5}$ minutes, why the fire had to be put out with a fire hose by opening access holes in the roof of the cave, how the radiation escaped, whether the workers were wearing protective clothing and how they got exposed. British Nuclear Fuels has refused to comment on the questions. "We are not prepared to answer questions which will cut right across the internal inquiry presently underway," an official told Nature. When complete the report will be released to the local liaison committee.

Joe Schwartz 